\title{
Notes on the Life-History of Pterostylis.
}

\author{
BY
}

OSWALD H. SARGENT.

With Plates XVIII and XIX.

DTEROSTYLIS is a genus of small terrestrial herbaceous orchids. Its members are chiefly found in Australia (including Tasmania). About forty-five species are known. One of these extends to New Caledonia, and several extend to New Zealand, the home of several species not found elsewhere. So far, ten species, viz. $P$. reflexa, constricta, nana, pyramidalis, recurva, vittata, Sargenti, nufa, barbata, and turfosa, have been reported from Western Australia. One of these, barbata, has not been seen by collectors for many years. All the remaining nine I have found within a few miles of my home (at York, W.A.), and have carefully observed them for several years. I have also cultivated the majority in flower pots. Upon these observations and experiments the present paper is founded. As the genus is a very natural one, there is little doubt that my conclusions based upon the study of a part will hold good with but little modification for the whole.

During the hot, dry summer months the plant exists as a small globular succulent tuber, buried two or three inches below the earth's surface. This tuber is strangely lacking in protective covering. There is no layer of dead fibrous tissue, as in Caladenia or Glossodia, and even the cuticle is remarkably thin. Doubtless the fibrous soil in which the plants grow forms a sufficient protection against undue loss of moisture. Some dormant tubers of $P$. Sargenti rapidly became flaccid when taken out of the ground; while on the other hand a tuber of $P$. rufa kept in a loosely covered box remained turgid right through the summer.

On the advent of the winter rains, about May, the tuber puts forth a single shoot. This grows rapidly, and as it grows develops numerous short processes all over each internode(subterranean). These processes are truncated cones of tissue whose apical layers consist of a number of thinwalled grape-shaped cells. These cells are attached at their bases only, and their function is without doubt the absorption of food salts from the soil.

[Annals of Botany, Vo1. XXIII. No. XC. April, 1909.] 
The processes on the internode next below the surface terminate in long thread-like cells, which give access to the mycelium of a fungus. This gradually penetrates to the cortex, filling its cells with a tangle of hyphae. I only discovered the presence of this fungus last year, and know very little concerning it. There is no doubt, however, that the orchids depend very largely on their fungal partners for a living. Their root system is always very scanty, only a few short roots being developed from the lowermost internode.

When the plant has spread its leaves and gained sufficient strength, a shoot is developed just above the tuber. This shoot grows straight down and ultimately thickens into a tuber, which replaces the old one, and forms the resting stage of the plant during the next summer. In the species reflexa, constricta, nana, and pyramidalis, secondary tubers are also formed in the following manner: one or more branches appear just below the fungal tissue. These grow horizontally, or slightly downwards until they attain a length of two or three inches. They then turn abruptly down and grow a little longer. The turned-down parts then thicken and become tubers. In this manner two or more plants are formed from the original one. It is doubtless, chiefly owing to this vegetative mode of reproduction, that these species are usually found in colonies, in which the plants are often very much crowded. I am sure, however, that seedlings assist in the formation of the colonies, as I have repeatedly found them therein. The other Westralian species do not form colonies, and I have never found them with long tuber-forming branches. Occasionally, however, they form two tubers instead of only one beside the old tuber. Usually only one of these produces a flowering scape the first year after formation.

The leaves of the young and non-flowering plants of all the Western Australian species are closely similar. Speaking broadly, they are ovate in outline, are borne on amplexicaul petioles (usually short), and are arranged in radical rosettes. P. rufa and nana retain this form of foliage all through their lives. The flowering plants in these species throw up scapes through the centres of the rosettes. In $P$. pyramidalis, turfosa, and barbata the lower internodes elongate at flowering time, so that the rosettes, as such, vanish, though the leaves still remain near the bases of the stems. In the remaining species the flowering and non-flowering plants are sharply differentiated. The latter, as I have stated, produce rosettes of ovate leaves ; but when a tuber of one of these species is in a fit condition to flower it throws up a strong scape bearing at intervals alternate, sessile, lanceolate leaves. There is no rosette at any time of the year in which the plant flowers.

The scape varies in height from a few inches $(P$. nana, reflexa, \&c. $)$ to a foot or more (vittata and recurva). The inflorescence is a loose few- or many-flowered raceme. In some species (nana, pyramidalis, reflexa, and constricta) it is reduced to a single flower, with usually the rudiment of 
a second at its base. True to its ordinal character, the flower develops with its face towards the axis of the plant. In most orchids the flower is brought face forwards by torsion of the ovary. In Pterostylis the ovary is not twisted. In the many-flowered species the stem above the flower's insertion leans to one side, and so leaves the face of the flower free from obstruction. The flower usually leans forward and thus appears on the side of the stem opposite to that on which it is inserted.

The flower itself is remarkable and rather complicated. I think its structure and mechanism can best be explained by taking the flower of $P$. reflexa as a type, and describing it in detail with the aid of Plate XIX, prepared by my friend, Mr. Stanway-Tapp. The anterior sepal (or so-called 'dorsal' because it forms the back of the flower) and the petals together form a galea, which much resembles a boat placed 'bows uppermost' (Fig. 2, $p, p$, and m.s.). The petals are attached to the sepal in a most ingenious way (Fig. 6). Each edge of the sepal (s.) is sharply bent inwards, and the tongue or flange thus formed fits so tightly into a groove in the petal $(p$.), that it is difficult to separate the parts without tearing. The lateral sepals are united for the greater part of their length from the base upwards. Their free apices diverge considerably and terminate in long filamentous antennae. It will be convenient to have a short, distinctive name for this structure (the conjoined lateral sepals), so I will follow the simile of a helmet and call it the visor. It stands erect in front of the galea in this species, and thus the lower part of the flower is completely closed, the diverging apices of the visor leaving the upper part of the galea widely open (Fig. 2). The labellum, always an interesting member of an orchid flower, is in this genus specially interesting. In the species under discussion a short, slightly cuneate, ribbon-like claw supports a long lanceolate lamina (Fig. I, l). At the base of the lamina a curious appendage arises. This appendage is a delicate strap of tissue ending in a few barbellate hairs. It is doubly curved : first transversely into a half-cylinder, thus securing rigidity; and then longitudinally so that it forms a semicircle. Its apex points upwards, the terminal brush being practically parallel with the face of the lamina (Fig. 8, $a p p$.). The column (Figs. 4, 5, and 10), which is arched over and completely enclosed by the galea, is a slightly curved fleshy pillar. It bears on its face about midway between base and apex two slightly sticky oblong cushions, the stigmas (Fig. 5). Just above these stigmas two large wings arise, one from each side of the column. These may be considered as originally rectangular bands of tissue, whose upper front corners have grown out into erect horns, and the lower front corners into large rounded lobes. These wings are curved, so that their edges almost meet in front of the column (Fig. 4). Thus a covered archway is formed in front of the column, the lower lobes bending outwards to touch the side of the galea. In this way the galea is divided into two chambers, an upper and a lower. The only means 
of communication between the chambers is the narrow passage or tunnel between the column-wings. An inwardly directed wrinkle on each side of the galea, extending some distance upwards from the base, considerably narrows the entrance to the lower chamber. The labellum fits this doorway pretty closely (Fig. I).

When the flower is open and ready to receive visitors, the labellum leans forward against the visor. In this position its tip protrudes a little from the flower and forms a convenient platform for insects to alight upon. The remainder of the lamina forms a sloping pathway down into the lower chamber of the galea. On the insect's arrival at the base of the lamina, the labellum suddenly springs back, hurling the insect against the stigmas. The lamina now leans against the column-wings (Fig. I), thus closing the lower chamber's doorway, and making the insect a prisoner. The insect may remain a prisoner till the automatic door falls open, which it will do in about half an hour; or it may at once escape by means of the tunnel between the column-wings. This course is most favourable to the flower. The tunnel narrows considerably towards the top, and once an insect arrives at this narrow part retreat is almost impossible.

The escaping prisoner makes his way through the tunnel with his back towards the column; and, when passing through the narrow part, its back cannot fail to come in contact with the sticky face of the rostellum, which is situate at the top of the column in front (Fig. 5). The anther, which is hinged to the top of the column behind the rostellum by a very short band of connective, partly obstructs the exit from the tunnel, so that the insect in emerging must lift it slightly. Each cell of the anther contains two bacilliform pollinia lying quite loose in the cell, one above the other. When an insect lifts the anther, the part of its back rendered sticky by contact with the rostellum comes against one or two of the rods of pollen, and these, adhering, are carried away from the flower. When free from the tunnel nothing remains to hinder the insect's departure. The flowers of $P$. constricta, nana, pyramidalis, and recurva, differ so little from that of $P$. reflexa, that I need not describe them; but it will be well to point out the conspicuous differences found in the flowers of the other Westralian species. In these the visor is sharply reflexed at its base, and hangs down in front of the ovary, and the labellum hangs down in front of the visor. In P. vittata the lamina is a small oval fleshy plate, and its appendage a mound of tissue, surmounted by a slightly hairy spike. In $P$. rufa the lamina is a fleshy rod without any specially differentiated appendage. In $P$. Sargenti the structure of the lamina is particularly remarkable. It may، be described as consisting of three lanceolate segments conjoined at the base, but free above for fully half their length. Each outer segment bears at its base a large flattened clavate appendage, which leans inwards, so that the apices of the two connive. Immediately behind these appendages there is a ridge of tissue, which 
I am inclined to think is the homologue of the appendage found in other species. The two large appendages are, I believe, quite peculiar to $P$. Sargenti. They seem specially designed to part the curious curtain, which closes the doorway of the galea. This curtain, also peculiar to the species, is formed by a fringe of delicate hairs arising from near the inner edge of each petal, and extending half way across the doorway. The large appendages readily push the fringes aside when the labellum flies back, and thus clear the way for the entrance of the insect when it is hurled into the flower. The fringes are sufficiently elastic to regain their former position when the labellum falls down.

The flowers of $P$. turfosa and P. barbata are closely similar, so a brief notice of the former will suffice for both. The lamina of the labellum is reduced almost to a thread. It ends in a clavate knob, and is rather sparsely fringed on either side with long golden hairs. Its appendage is a short flat rod, which looks like a continuation of the lamina back beyond its insertion on the claw. This strange structure leans a little away from the galea in the open blossom. When excited it moves back and forms a curtain across the entrance.

Now in all these species the labellum is highly irritable : a very light touch, while it is in the ready-to-receive-visitors position causes it to fly back and close the lower chamber of the galea. Rough trials with the finger or some heavy instrument lead one to suppose that the lamina is sensitive all over; but careful experiments with a bristle have convinced me that the sensitiveness is really localized in the appendage. Observations support this conclusion. I have seen insects alight on the labella of P. rufa, Sargenti, and vittata, and fly off again without having set the labella in motion. In each case the insect failed to touch the appendage, and experiment immediately after its departure showed the labellum to be in a highly irritable condition. The insects in question are tiny diptera. I weighed one like that which I saw hurled into a $P$. Sargenti blossom: its weight was just one milligram. So far as I could see it touched the sensitive spot with one fore-leg only, so that the pressure upon the spot must have been considerably less than a milligram. From this, some idea may be gleaned of how very ticklish the labellum is. The large appendages of $P$. Sargentiare not sensitive to a gentle touch. The sensitive spot lies between them at the base of the ridge, which I regard as a third appendage. This is one of my reasons for believing this ridge to be the homologue of the appendage found in other species.

Having flown back, the labellum continues to keep each flower closed for a considerable length of time. If it be pulled forward it springs back immediately on release. The duration of closure varies with the species, In $P$. turfosa it is about 25 minutes, in $P$. reflexa about 35 , in $P$. constricta 
about 40, in $P$. Sargenti about 35 , in $P$. vittata about 2 hours, and in $P$. recurva about 3 hours, during the warmer hours of the day. These times are usually doubled before 10 a.m. and after 4 p.m., and throughout dull days. There are many variations; but good healthy specimens can generally be relied upon to keep pretty close to the times I have given. Perhaps departures from the usual time are always evidence of something wrong. The same specimen, however, often varies its time a little from day to day.

Time being up, the labellum returns to the 'ready' position sometimes abruptly, sometimes by several short jerks, and sometimes with a continuous, slow, even motion. Even the same labellum behaves differently in this respect on different occasions.

The appendage is not immediately sensitive to touch, when the labellum has reached the 'ready' position. Irritability is regained after a lapse of time, varying in different species from a few minutes to half an hour. The labellum is insensitive, I believe, all the while that the flower is closed. Tickling the appendage with a bristle while in that position seems to have no effect on the duration of closure.

Let us now leave mechanical details and examine the plants 'at home'. In my experience they are almost always found in shady situations, under bushes or amongst rocks. The flowers are remarkably inconspicuous in their natural surroundings (Pl. XVIII). Being mostly greenish-white with green longitudinal markings, or bands, they appear green. $P$. reflexa is rufous, and $P$. rufa, I believe, is usually so, though most of the specimens I have collected are green. $P$. vittata occurs in two forms, green, and deep reddish brown. $P$. reflexa blooms early in the season, and its rufous blossom is not readily seen against the background of dull brown earth and yellowish dead vegetation. Even its later flowers amongst green grass must be looked for to be seen. The flower of $P$. constricta is green; and when the plant grows amongst grass, it is decidedly difficult to see. $P$. Sargenti has a deep green flower, easily overlooked as the plant usually grows in dark coloured soil. $P$. recurva and $P$. turfosa are well hidden by the tangle of bushes, amongst which they occur. My experience of $P . r u f a$ is that the grey-green flowers harmonize so well with the green-grey granite inhabited by the plant, that I have often looked hard at a specimen for several minutes before seeing it.

To this lack of conspicuousness add the facts that the flower is odourless and devoid of nectar, and take into consideration the irritability of the labellum ; and the conclusion that the flower is nothing but a trap is almost inevitable. But that is not all, there are other things to be reckoned with. I have often found the flowers of $P$. vittata and $P$. Sargenti with their labella missing. It seemed they had been gnawed off. This points to there being something attractive about the labellum. The behaviour of the diptera, which visit the flowers, strengthens this idea. I have seen these 
insects hovering over the labella just as bees do over nectariferous blossoms. On one occasion I saw a little dipteran sucking juice from the top of a large appendage of a $P$. Sargenti labellum. I have noticed also that the diptera which visit $P$. Sargenti flowers are often in no hurry to leave their prison, when hurled into it. Quite unconcernedly they employ their time in sucking juice chiefly from the lower part of the column. One sometimes continues thus employed till the labellum falls and allows it to escape without crawling through the column wings. After such a long stay in the flower the insect always seems rather stupid and disinclined to fly, until it has spent a few minutes in the open air. Its behaviour suggests intoxication, though it walks quite steadily. A fortunate accident gave me the hint that 'blow flies' are fond of the juice of these orchids. Acting on the hint, I caught a few vigorous flies and imprisoned them under a bell-glass along with a watch-glass containing a crushed $P$. recurva blossom. Very soon the flies were greedily feasting on this. At first they were easily disturbed ; but it gradually became difficult, and finally almost impossible, to drive them from their booty. Then they seemed unable to fly, though they could walk perfectly. I replaced the Pterostylis flower with a dish of pure water, and the flies rapidly regained their former liveliness. At another time I saw a blow fly greedily sucking the top of the ovary of a $P$. recurva flower, from which I had cut the perigone and column. This fly clung tenaciously to his prize when I tried to pull him off. As soon as I let go he sprang back, as though his legs were rubber bands fastening his body to the ovary, and recommenced sucking immediately. Even tickling his proboscis with a stiff bristle made no impression upon him. Similar experiments with $P$. Sargenti blossoms gave concordant results.

I think it is safe to conclude that the flowers contain an intoxicating principle highly attractive to the insects which visit them. I may here remark that tiny insects (diptera) are not infrequently found dead in the flowers, usually adhering to the stigma. The stigma is so slightly sticky, indeed it is scarcely more than moist, that I have always very much doubted its ability to hold a living insect, even though so small a one. I now feel sure that these little flies found dead in the flowers are victims to their unbridled appetites. Only once have I seen a visit to a flower carried completely through. I will briefly describe it. On July I7, I907, a vase containing several racemes of $P$. vittata was standing close to my window. At about 3 p.m. I noticed a small ' $g$ nat' hovering over the flowers apparently choosing a labellum to settle upon. Soon it did alight on one, but quickly flew off again. It shortly returned, and again settled on the same labellum. It settled near the apex and gradually moved up to the base of the lamina. I believe it then thrust its proboscis into the fleshy tissue of the appendage. Then the labellum immediately sprang back, and made the gnat a prisoner. After fluttering about for a few seconds in the lower chamber, 
the gnat commenced to climb through the tunnel formed by the column wings, with its back towards the column. It had to struggle violently to get through the narrow top of the tunnel, but within three minutes after its capture it was free again. It settled on the window, where I easily caught it. After killing it with chloroform I found that it bore two pollen-masses on its back.

Thrice I have seen an insect struggle through the tunnel of a $P$. Sargenti flower, but more often these insects have shown no desire to leave their prison. Once I saw a dipteran hurled into a flower of $P$. Sargenti. It immediately set about sucking juice. I watched the flower for twenty-five minutes, at the end of which time the insect managed to escape by squeezing past the labellum, the flower having been damaged at one spot. I have not seen any other species visited. All the diptera I have seen in P. Sargenti flowers appear to belong to one species, and they pay no attention to other species of Pterostylis. The insect I saw visit a $P$. vittata blossom was very different; I should think it belongs to a separate genus. I have several times seen, what seemed yet another kind of dipteran, hovering over the flowers of $P$. rufa. A fourth kind I have seen hovering round $P$. nana flowers, and a fifth I have found dead in a flower of $P$. constricta. It seems that each species is pollinated by its own special species of dipteran, as careful examination of the flowers leads one to expect. Closely allied species are exceptions to this rule. I have found hybrids between $P$. reflexa and $P$. constricta. Rodway reports hybrids between $P$. concinna and $P$. praecox in Tasmania, and Ewart announces the discovery of hybrids between $P$. concinna and his 'var. intermedia' of $P$. reflexa, in Victoria.

My observations are insufficient to enable me to deal exhaustively with the pollination of these flowers, but I have formed a working hypothesis, which, because it seems to me so very probable, I will venture briefly to expound. The first time an insect is hurled into a flower it is so alarmed that it immediately seeks a way of escape. This it soon finds in the column-wings tunnel, and, as it struggles through, a load of pollen is fastened to its back. The attraction of the flower is great, and it is not long before the insect again alights on a labellum, and is a second time hurled into a flower. Its pollen-covered back strikes the stigma, which removes a portion of the load. Less alarmed on this occasion the insect probably lingers and sucks the intoxicating juice. A little suffices this time, and the dipteran seeks freedom via the tunnel. A few more flowers may be visited in a similar manner, but the time soon comes when the dipteran lingers in the blossom till the labellum falls, and then makes its exit without passing through the tunnel. Then, when next it visits a flower its stock of pollen will be comparatively small, but it will linger long, and brushing frequently against the stigma will coat that organ with a sufficient number of the precious grains.

I refrain from recounting all the observations which have enabled me to 
formulate the above hypothetical account of the adventures of a dipteran, because at present it is only a working hypothesis.

I think I have shown that the flowers are very cunningly devised. Intoxicating juice and irritable labellum seems a remarkably good combination. But the best laid schemes do not always succeed, and the question arises: how effective is this one? How shall we judge? If seed production is to be the criterion, we shall receive an indefinite answer. Some species (e. g. P. reflexa, constricta, and rufa) are very shy seeders, but others seed freely, $P$. recurva sometimes gets over ninety per cent. of its flowers fertilized. But even supposing that the majority of species usually get but a small proportion of their flowers fertilized, it does not necessarily follow that the method of pollination is to blame. It might be thought that the sensitive labella would frequently be excited to close the flower by causes other than the alighting of desirable insects; but this is not the case. Very seldom is a blossom found with its labellum closing the lower chamber. Wind, unless perhaps a very strong one, does not affect the labellum. The fact that over forty species of this genus are in existence, scattered over a vast continent, is surely strong evidence that their reproductive mechanism has proved effective in the past. As to the future; five years' close observation has given me the impression that the species I know are well able to hold their own in their native wilds. I have no data for forming an opinion as to the effect civilization will have on them.

I have not exhausted the resources of my notebook, but I think I have said enough for the present. I have sought in this paper to give a clear idea of the impressions I have formed, so I have not tried to demonstrate any of my statements. Much that is interesting I have reluctantly omitted. I am continuing my observations and experiments, and I hope from time to time to deal with individual points in full detail.

In conclusion, I wish to express my indebtedness to Professor Oliver, Dr. A. B. Rendle, and Dr. R. S. Rogers (of Adelaide, S.A.), for much help and encouragement in various ways.

\section{LITERATURE.}

R. D. Fitzgerald : Australian Orchids. Sydney, i882.

J. D. Hooker: Flora of Tasmania, vol.ii, p. I8.

F. W. Oliver: On the Sensitive Labellum of Masdevallia muscosa, Rchb. f., Ann. of Bot., vol. i, p. 246. 


\title{
274 Sargent.-Notes on the Life-History of Pterostylis.
}

\section{EXPLANATION OF PLATES XVIII AND XIX.}

\author{
Illustrating Mr. O. H. Sargent's paper on Pterostylis.
}

\section{PLATE XVIII.}

Flowering specimens of Pterostylis reflexa growing in their natural surroundings.

\section{PLATE XIX.}

\section{All figures are Pterostylis reflexa.}

Fig. I. Side view of flower, one sepal, petal, and part of galea removed to show internal arrangement. $l$. the labellum in the contracted position; its appendage is seen below.

Fig. 2. Front view of flower, one sepal removed. p.p. lateral petals; m.s. median sepal-the three collectively forming the galea. l.s. lateral sepal.

Fig. 3. Side view showing petal; one sepal and part of galea removed. c. column. Sections of the petal at various heights are shown on the right.

Fig. 4. Column (front view).

Fig. 5. Column (wings spread open). anth. anther; rost. rostellum; stig. stigma.

Fig. 6. Section showing attachment of petal to galea. $p$. petal; s. sepal.

Fig. 7. Labellum viewed from within. $a p p$. appendage.

Fig. 8. Labellum (side view). $a p p$. appendage; on right section of blade.

Fig. 9. Top of column and one wing.

Fig. 10. Side view of column. 


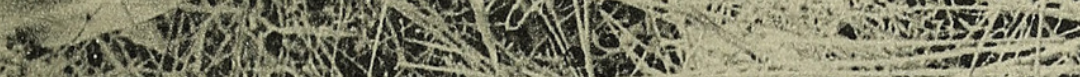

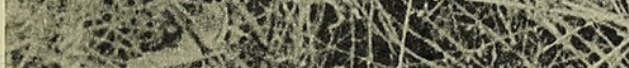

Qo.

9.6.

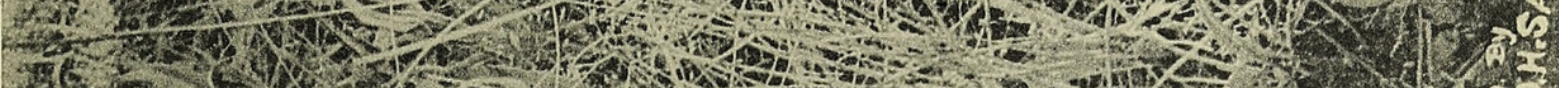

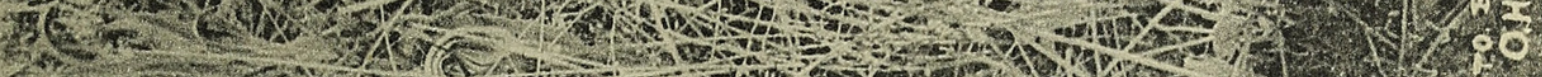

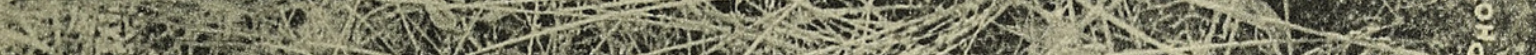
T.

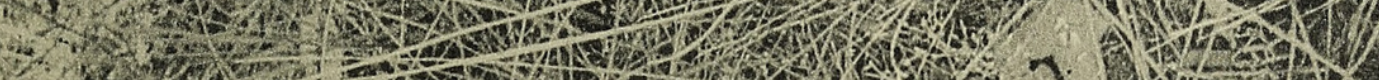
(1.7.

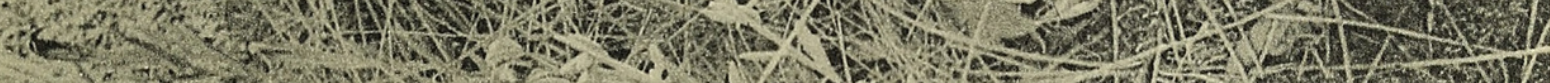
7.. $\%$.

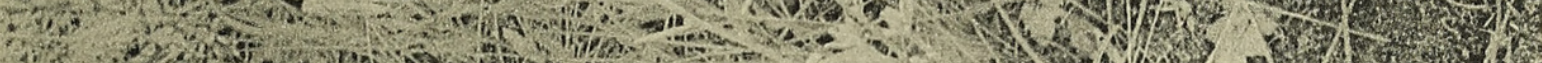

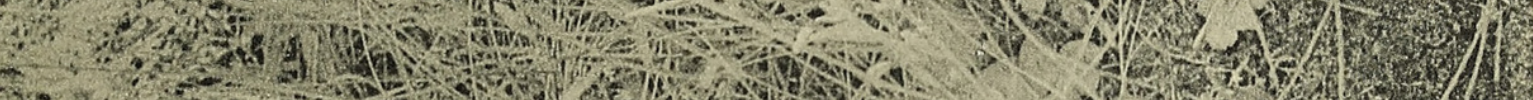

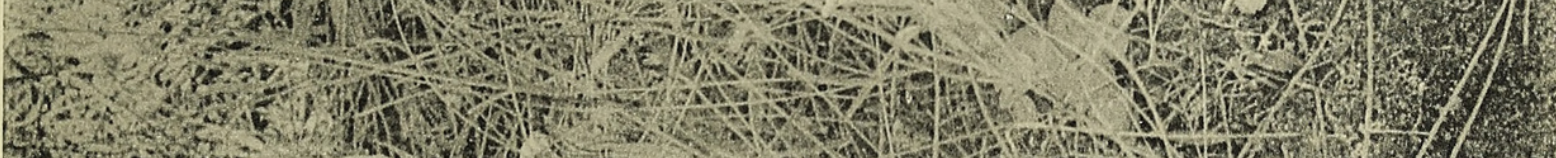

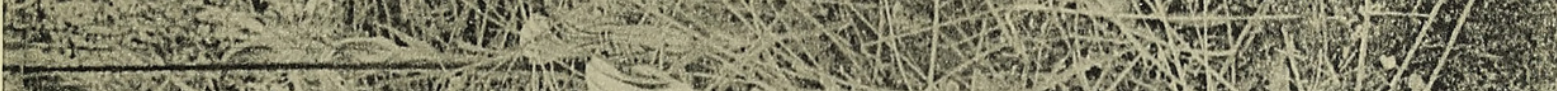

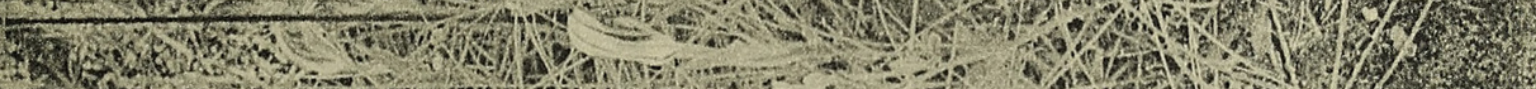

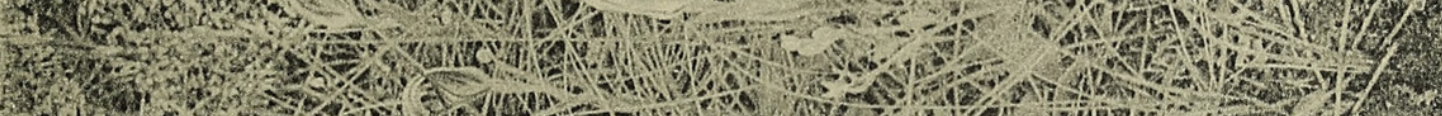

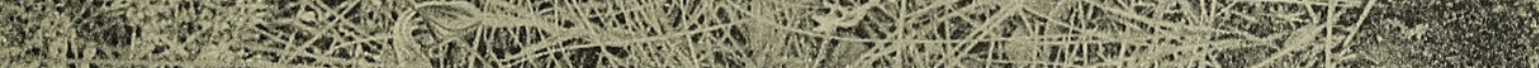
- 2 ,

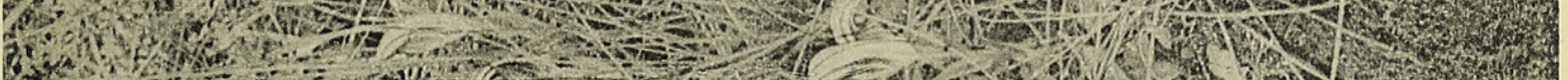

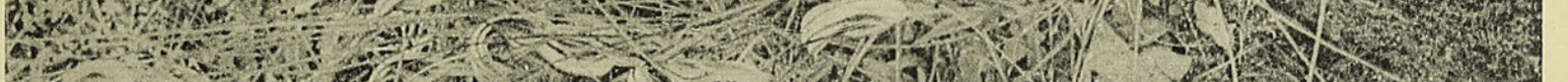

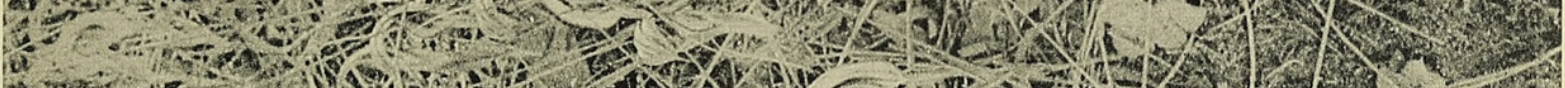

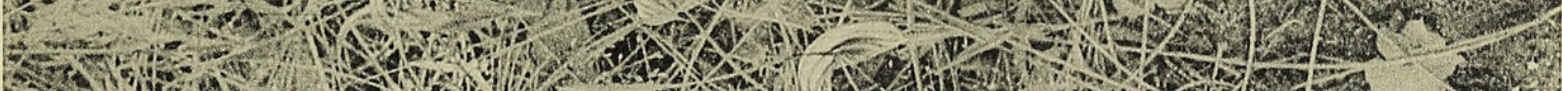

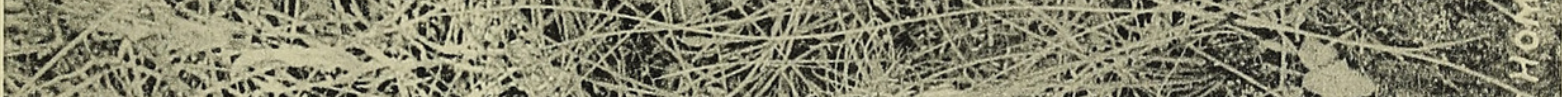
3. 2. 20.

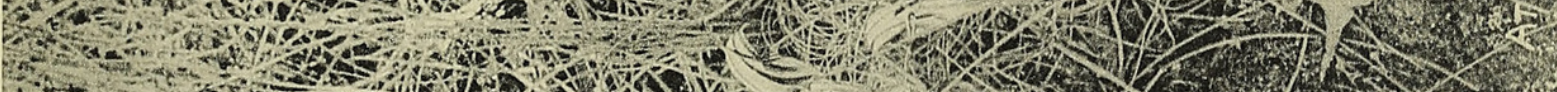

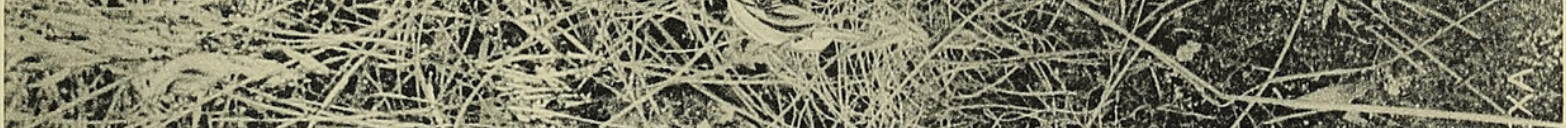

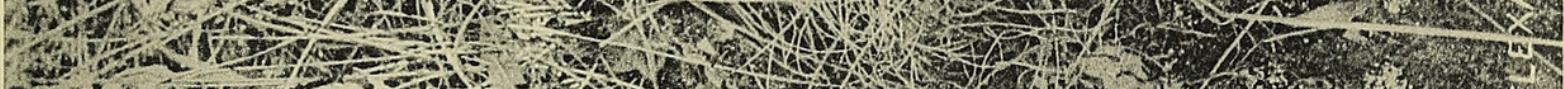

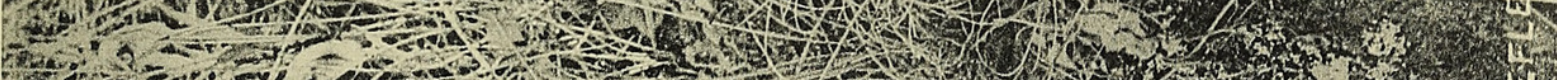
- 1.

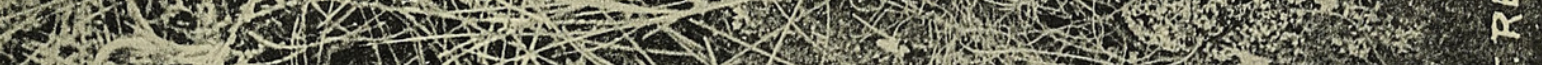
5.t. S.7. 


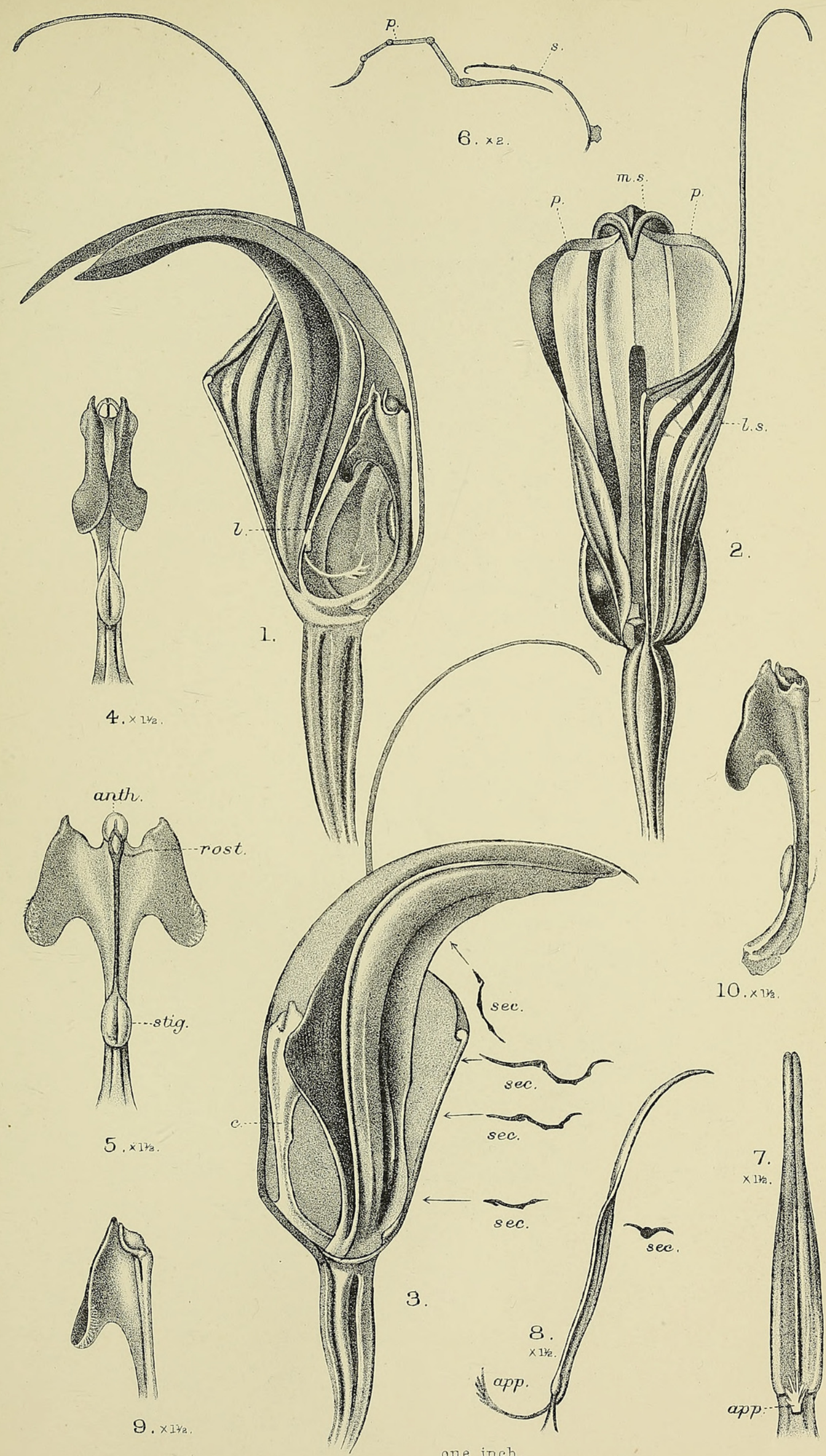




\section{$2 \mathrm{BHL}$ Biodiversity Heritage Library}

Sargent, Oswald H. 1909. "Notes on the life-history of Pterostylis." Annals of botany 23, 265-274. https://doi.org/10.1093/oxfordjournals.aob.a089214.

View This Item Online: https://www.biodiversitylibrary.org/item/236540

DOI: https://doi.org/10.1093/oxfordjournals.aob.a089214

Permalink: https://www.biodiversitylibrary.org/partpdf/318950

\section{Holding Institution}

Smithsonian Libraries

\section{Sponsored by}

Biodiversity Heritage Library

\section{Copyright \& Reuse}

Copyright Status: Not in copyright. The BHL knows of no copyright restrictions on this item.

This document was created from content at the Biodiversity Heritage Library, the world's largest open access digital library for biodiversity literature and archives. Visit BHL at https://www.biodiversitylibrary.org. 